The BMJ

jsilberner@bmj.com

Cite this as: BMJ 2021;372:n142 http://dx.doi.org/10.1136/bmj.n142 Published: 19 January 2021

\section{US HEALTH}

\section{How Joe Biden plans to heal American healthcare}

The world's highest number of covid deaths, a broken healthcare system, and a mess of unhelpful regulations put in place by his predecessor-Joanne Silberner examines what the incoming US president has to contend with and how he intends to fix things

Joanne Silberner US coronavirus news editor

During his 2020 US presidential campaign the Democratic candidate Joe Biden had some clear goals: expand access to health insurance, simplify the country's notoriously complex healthcare system, cut the costs of prescription drugs, and expand access to abortion. ${ }^{1}$ Then covid-19 cast a shadow on the whole presidential race.

As Biden takes the oath of office on 20 January he faces the immediate challenge of dealing with the pandemic hurricane buffeting the US and reversing years of undercooked protection and prevention measures.

But he does have one thing on his side that he might not have expected at the beginning of the campaign: control of the US Senate, which the Democrats won in a closely fought 5 January election. With his party now in control of the White House, Senate, and House of Representatives, Biden has a good chance of getting at least some of his agenda approved.

Still, the Democratic majorities in the House and Senate are slim, and some Democrats lean towards the conservative side, and some types of legislation require a "supermajority." Health experts are divided on the fate of two of the president elect's more ambitious plans: allowing an insurance plan run by government to compete against private insurers in the Affordable Care Act (also known as Obamacare, introduced under Barack Obama and while Biden served as vice president) and lowering the age of eligibility for Medicare, the government insurance programme for people aged 65 and older.

But the Senate majority does give Biden free rein to pick his own people for top posts without having to compromise with the Republicans. He may be able to open up and make some changes to Obamacare that will nullify a pending Supreme Court decision that could otherwise threaten its viability.

There are also several dozen more health related policy changes that Biden has the power to make without Senate approval. ${ }^{2}$

But first he has to confront covid-19.

\section{Pandemic action}

Biden has been regularly briefed on the pandemic by respected scientists, including Anthony Fauci, head of the National Institute of Allergy and Infectious Diseases, ${ }^{3}$ who had been sidelined by Donald Trump's administration. Biden has set up a scientific advisory board, ${ }^{4}$ and reportedly he demands regular updates from his staff on how vaccination planning is going, although staffers have complained that Trump's officials have been slow to provide data.

Biden will be asking all Americans to wear masks for his first 100 days in office, a major change from Trump, who rarely wore one and refused to endorse the practice. But the president has limited authority over mask wearing. It is the states that bear most of the responsibility for public health measures, and mask mandates vary across the country. Biden has said he'll urge local and state governments to do their own mandates and require mask wearing on federal property and on interstate transport.

With vaccines, his incoming administration is grappling with an uneven rollout that the Trump administration had basically left up to individual states, which are getting free vaccines but little funding for distribution.

Biden has promised 100 million vaccinations in his first 100 days. ${ }^{5}$ Politico reports that the president elect has serious concerns about delivering on this, given the lack of structure and resources officials are encountering in the transition period. ${ }^{6} \mathrm{He}$ has also said he'll be pushing to get first doses administered as quickly as they can be made and distributed, rather than holding back vaccine stocks for people's second doses.

Five days before his inauguration, Biden warned Americans that things would get worse before getting better. He said he'll be asking Congress for another \$2obn to speed up federal vaccination efforts, will be dropping the name "Operation Warp Speed," and is looking to extend insurance subsidies to more of the middle class. ${ }^{7}$

\section{Undoing}

Three days after his inauguration in 2017 Trump announced the revival of the "Mexico City plan," sometimes known as the global gag rule. In its usual form this plan blocks family planning clinics anywhere from receiving federal family planning funding if they provide abortion or abortion counselling.

The rule has been the pivot in a game of seesaw that has lasted more than 30 years. First implemented by Ronald Reagan in 1984, Democratic presidents cancel it the first chance they get. Republican ones reinstitute it on taking office. Trump's version-the harshest yet-banned not just family planning funding to any clinic that even mentioned abortion 
to its patients but also funds earmarked for treating HIV, malaria, and other infectious diseases. The policy quickly led to reduced access to family planning services in poor countries. ${ }^{8}$ Biden has promised to cancel it early on.

He has also promised to strengthen the Affordable Care Act, Obama's signature expansion of health insurance, which Trump vowed to repeal and replace. Throughout his presidency Trump repeatedly promised a new and better plan but never introduced one. He was, however, able to weaken Obamacare in several ways, including by cutting funding for public information about the insurance programmes, allowing people to buy insurance that didn't offer all the benefits covered by the Act, and allowing insurance policies that didn't cover pre-existing conditions.

\section{Back on the world stage}

The Trump presidency had seen the US step back from global health leadership like never before, epitomised by the president's July 2020 announcement that he was pulling the US out of the World Health Organization.

But the process takes a year, and Biden has promised to cancel the pull out on his first day in office. Biden will also be putting back in place a job eliminated by Trump, a high level appointment for global health security and biodefense.

Chris Jennings, a long time health adviser to Democratic administrations, told Kaiser Health News that the Trump administration has left "bird droppings" that must be dealt with to have a clean slate. ${ }^{9}$ One of the most worrisome for the scientific community is a rule that prohibits the Environmental Protection Agency from considering the results of studies on pollution and other environmental issues unless the raw data are available. And since most of the relevant research relies on confidential patient information, the need for privacy and anonymity would mean many of the most conclusive studies would be off limits.

Another recently finalised rule requires the agency to ignore the economic costs of illnesses and deaths when totting up the total costs of air pollution. Which brings us to climate change. Citing his "America First" policy, Trump started the process of withdrawing the US from the Paris Agreement early in his presidency. The withdrawal was finalised on 4 November, the day after voting for the presidential election closed. Biden has promised to rejoin on the first day of his presidency.

\section{Fixing the healthcare "system"}

The Department of Health and Human Services (HSS) runs the Food and Drug Administration, the Centers for Disease Control, various government health insurance programmes, drug treatment agencies, and more. During his tenure Trump regularly second guessed or ignored advice from the agencies, and morale throughout HHS is low.

Don Berwick, a senior fellow at the Institute for Healthcare Improvement and former head of Medicare and Medicaid (the health care programme for poor and disabled people), thinks the way to get things moving again is to start with morale. "From what I'm hearing, there's a level of demoralisation among people who've spent their careers trying to make good federal programmes that is profound," he says.

HHS will need to create new programmes, bolster old ones, and reverse some changes instituted by Trump, says Berwick, who was an adviser to the Biden presidential campaign. He expects to see renewed interest in fighting the opioid epidemic, which has been overlooked during the pandemic. ${ }^{10}$
On 8 January the Trump administration permitted the state of Tennessee to fundamentally change the financing for Medicaid. The new programme gives the state more power over how federal funds are spent, while putting a cap on total funding, regardless of need. Such an approach could destroy the programme. The New York Times reported that the current head of Medicaid has been pressing states to sign contracts that would make it difficult for them to alter any special deals they've made with the Trump government, which could make the Tennessee plan difficult to cancel. ${ }^{11}$

One of Trump's rare bipartisan actions, taken just before the end of his presidency, was to sign legislation that eliminates "surprise billing" as of 2022. This is where a patient goes to a hospital that is part of their insurance plan but where the anaesthesiologist or the surgeon, say, may not be covered by that plan. Patients in the US regularly wake up from surgery to bills of thousands or tens of thousands of dollars for care that would have entailed only a small copayment had the doctor been in the plan.

Now Biden's people get to write the rules for one of the few health laws to come out of the Trump years that benefits patients.

Competing interests: None declared.

Commissioning and peer review: Commissioned, not externally peer reviewed.

Rovner J. US election 2020: how the candidates will determine the shape of American healthcare. BMJ2020;371:m3947. doi: 10.1136/bmj.m3947 pmid: 33051181

2 Cox C, Kates J, Pollitz K, et al. Potential health policy administrative actions under President Biden: issue brief. Kaiser Family Foundation. 8 Dec 2020. https://www.kff.org/report-section/potentialhealth-policy-administrative-actions-under-president-biden-issue-brief.

3 Godlee F, Silberner J. The BMJ interview: Anthony Fauci on covid-19. BMJ 2020;370:m3703. doi: 10.1136/bmj.m3703 pmid: 32967907

4 Silberner J. Fixing America's covid response in the Biden era. BMJ2021;372.

5 Tanne JH. Covid-19: Biden calls for science, vaccines, and masks. BMJ 2021;372:n150doi: 10.1136/bmj.n150.

6 Cancryn A, Pager T. Biden dresses down his covid team over plans to speed vaccinations. Politico 11 Jan2021. https://www.politico.com/news/2021/01/11/biden-coronavirus-vaccine-goal-problems457245.</eref〉

$7 \quad$ Kliff S, Sanger-Katz M. One sentence in Biden stimulus plan reveals his health care approach. New York Times. 16 Jan 2021. https://www.nytimes.com/2021/01/16/upshot/biden-obamacarestimulus.html.

$8 \quad$ Adhikari R. US "global gag rule" on abortion is limiting family planning choices for women in Nepal. BMJ 2019;366:15354. doi: 10.1136/bmj.15354 pmid: 31506255

9 Rovner J. Biden's first order of business may be to undo trump's policies, but it won't be easy. Kaiser Health News. 8 Jan 2021. https://khn.org/news/article/bidens-first-order-of-business-may be-to-undo-trumps-policies-but-it-wont-be-easy.

10 Arnold C. The US covid pandemic has a sinister shadow-drug overdoses. BMJ2020;371:m4751. doi: 10.1136/bmj.m4751 pmid: 33334731

11 Sanger-Katz M. An 11th-hour approval for major changes to Medicaid in Tennessee. New York Times. 8 Jan 2021. https://www.nytimes.com/2021/01/08/upshot/medicaid-tennessee-trumpbiden.html. 